\title{
The genus Cliffortia (Rosaceae) in KwaZulu-Natal
}

\author{
C.M. WHITEHOUSE*
}

Keywords: area of endemism. Clifforia L., Drakensberg. KwaZulu-Natal, Rosaceae

ABSTRACT

\begin{abstract}
The only area of endemism for Cliffortia L. outside of the Cape Floristic Region (CFR) is centred in the northern KuaZuluNatal Drakensberg. Eleven species of Clifforia have been recorded from KwaZulu-Natal and distribution maps are provided for each. Clarification of the circumscription of $C$. browniana Burtt Davy is discussed and a new species, $C$. dracomontana, is described. C. paucistaminea Weim. is subdivided into two varieties: var. australis and var. paucistaminea. Comments on some of the other species that have frequently heen misidentified are also provided along with a key to all the species in the area.
\end{abstract}

\section{INTRODUCTION}

Cliffortia L. is the largest southern African genus within the Rosaceae. It was last comprehensively revised by Weimarck $(1934,1948)$ and subsequent published work has focused upon describing new species and clarifying taxonomy (Weimarck 1953, 1959; Oliver \& Fellingham 1991, 1994; Fellingham 1993a, b. 1994, 1995. 2003). Recent work by Whitehouse (2003) using morphological and molecular techniques has indicated that some of the species boundaries need revising to reflect more accurately the diversity found within Cliffortia.

Cliffortia has its centre of diversity in the Fynbos Biome of the Cape Floristic Region (CFR) and over $80 \%$ of its species are endemic to that region (Goldblatt \& Manning 20(0): Whitehouse 2003). Linder (2001) stated several criteria to define areas of endemism: each area should contain at least two endemic species; the areas must be mutually exclusive; the areas must be narrower than the study area and several areas need to be defined for any discussion about their biogeography to be interesting: and finally, the ranges of the endemic species should be optimized to be maximally congruent. Using these criteria, only a single area of endemism exists outside of the CFR and is centred on the northern $\mathrm{KwaZulu}$ Natal Drakensberg (Whitehouse 20(03).

Eleven species of Cliffortia have been recorded within KwaZulu-Natal. C. odorata L.f. is recorded from a single old collection near Port Shepstone (Alexandra District, Hlokozi, 22 Feb. 1916. Rudatis 2242). The remaining species are either endemic to the Drakensberg or widespread, though scattered, through the province. C. filicauloides Weim. and C. spathulata Weim. are endemic to the northern KwaZulu-Natal Drakensherg. whereas the newly described species $C$. dracomontana C.M.Whitehouse is also endemic to the main Drakens-

\footnotetext{
* Bolus Herharium. University of Cape Town, 7700) Rondebosch. Cape Town

MS. received: 2(0)3-02-14
}

berg escarpment but is found as far south as Ben Macdhui in Eastern Cape.

Despite the limited number of species present, the taxonomy and identification has often been confused. The flowers are small and remarkably uniform with few diagnostic characters. Therefore, species determination is primarily based upon vegetative characters, especially leaf form and achenes when present. However, whereas several species are easily determined from the leaves of their mature plants, their juvenile foliage (i.e. the first few true leaves of seedlings or of new shoots resprouting after a fire) is morphologically very different. Seedlings and resprouting plants of Cliffortia have frequently been incorrectly labelled as unrelated species and this has confounded the identification of otherwise easily discernible species. Mature plants also sometimes show ecotypic variation in the size and shape of their leaves. especially on the borders of forest or rivers compared with more exposed slopes. Furthermore, the possibility of hybridization and subsequent introgression as found in several Cape species (Weimarck 1934: Fellingham 1993a: Whitehouse 2003) cannot be dismissed, although no confirmed examples have yet been demonstrated within KwaZulu-Natal. A key is presented here that attempts to take account of these variations and to identify species. where possible, even when only juvenile foliage is present.

The conservation status of all the KwaZulu-Natal species of Cliffortia should be regarded as 'lower risk. least concern for IUCN Red Data List assessments (Golding 2002). The widespread species are common and often weedy. In particular. $C$. linearifolia and $C$. nitidula subsp. pilosa are sometimes dominant and have then been used in defining certain vegetation types (e.g. Killick 1963: Edwards 1967). The endemic species are more localized but all grow within the protected area of the uKhahlamba-Drakensberg Park, generally on the higher slopes and in more inaccessible areas. As a result. although currently only recorded from a few scattered localities, they are probably present and common in the intervening parts of their ranges too. 


\section{Key to KwaZulu-Natal species of Cliffortia}

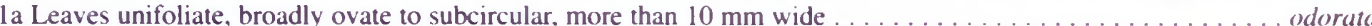

lb Leaves linear to obovate, less than $10 \mathrm{~mm}$ wide:

2a Leaves unifoliate, narrowly oblong, usually more than $20 \times 2 \mathrm{~mm}$; growing in or beside water ....... strobilifera

2b Leaves less than $20 \mathrm{~mm}$ long, if longer then belonging to a juvenile plant and trifoliate with needle-shaped leaflets:

3a Leaves with petiole; leaflets broadly obovate and at least middle leaflet toothed:

4a Plants decumbent or with arching stems; outer leaflets narrower than middle leaflet and only middle leaflet toothed; leaves sparsely hairy, sometimes only on midrib and margins; endemic to northern Drakensberg between Loteni River and Cathedral Peak . . . . . . . . . . . . . . . . filicauloides 4b Plants erect; middle leaflet similar to outer leaflets, all toothed: leaves hairy throughout . . . . . . . . . . . . .

$3 \mathrm{~b}$ Leaves without petiole, or if present then leaves oblong to linear and not toothed: nitidula subsp. pilosa (juvenile foliage)

5a Leaves unifoliate:

6a Medium to tall shrub with virgate or tangled stems; young stems densely hairy; leaves with midrib and margins thickened so that they touch each other; sepals 4; stamens 4; stigma white to pinkish . linearifolia

$6 \mathrm{~b}$ Low shrub with spreading stems that ascend towards apex; young stems glabrous or sparsely and very shortly hairy: leaves without noticeable thickening on midrib or margins; sepals 3; stamens 6; stigma

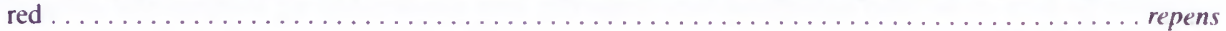
5b Leaves trifoliate

7a Leaves sparsely hairy especially on young growth: margins usually inrolled beneath . . . . nitidula subsp. pilosa $7 \mathrm{~b}$ Leaves always glabrous: margins not inrolled although sometimes thickened

$8 \mathrm{a}$ Very short petiole. $<1 \mathrm{~mm}$ long, often evident: leaves narrowly oblong, $2-8 \times 0.5-1.0 \mathrm{~mm}$, mucronate to rounded at apex; sepals $3 \ldots \ldots \ldots \ldots \ldots \ldots \ldots \ldots \ldots \ldots$ ramosissima* 8b Petiole absent; sepals 4 , very rarely 3 and then leaves needle-shaped with sharply pointed apex:

9a Leaves linear to needle-shaped:

10a Resprouting plants with leaflets more than $10 \mathrm{~mm}$ long, sterile:

lla Stems densely, shortly hairy .......................... linearifolia (juvenile foliage)

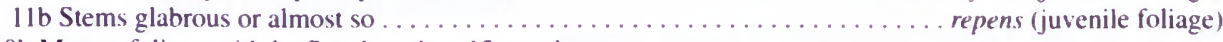
$10 \mathrm{~b}$ Mature foliage with leaflets less than $13 \mathrm{~mm}$ long:

12a Midrib and margins of leaflets thickened so that they touch each other: apices obtuse to rounded

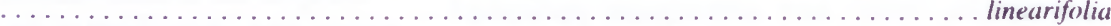

2b Margins of leaflets not thickened: midrib slightly thickened to form a keel; apices acute to long acuminate:

13a Leaflets curved upwards and towards stem, giving a feathery appearance to branch; George to Port Elizabeth . . . . . . . . . . . . . . . . . . . paucistaminea var alis

$13 \mathrm{~b}$ Leaflets straight or curved downwards and away from stem: brachyblasts sometimes appearing star-shaped; Port Elizabeth to KwaZulu-Natal . . . . . . . . paucistaminea var. paucisfaminea 9 b Leaves narrowly elliptic to broadly obovate:

14a Leaves glaucous: margins always entire: bracteole margins smooth: achene $3-5 \mathrm{~mm}$ long:

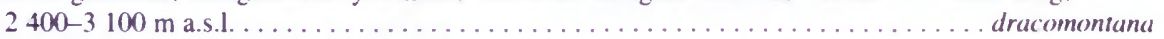

1 tb Leaves glaucous or not: at least juvenile leaves toothed: if mature leaves entire then bracteole margins shortly ciliate and achene less than $3 \mathrm{~mm}$ long:

15a Leaves broadly obovate, $1-4 \mathrm{~mm}$ wide; mature leaves toothed; achene $3-4 \mathrm{~mm}$ long; $1800-2800 \mathrm{~m}$ a.s.l. . . . . . . . . . . . . . . . . . . . . . . spathulata

15b Leaves elliptic to narrowly obovate, $0.5-2 \mathrm{~mm}$ wide; mature leaves entire; achene less than 3 mm long:

16a Leaflets narrowly elliptic; apices obtuse to acute: achene darkish brown. indistinctly ribbed;

$1000-2500 \mathrm{~m}$ a.s.l. bronniana

$16 \mathrm{~b}$ Leaflet narrowly elliptic to obovate; apices rounded to obtuse; achene beige to pale brown, clearly ribbed; $0-1600 \mathrm{~m}$ a.s.l. . . . . . . . . . . . . . . . . . . . . . serpvllifolia

\section{Identity of $\mathrm{C}$. browniana}

One species that has been particularly misunderstood in the past is $C$. browniana Burtt Davy. Its type collection was from the Mpumalanga Drakensberg escarpment near Lydenburg, from where several similar collections have subsequently been made. Morphologically, C. browniana has no unique diagnostic character and is very difficult to separate from some small elliptic-leaved forms of C. serpyllifolia Cham. \& Schltdl., with which it has often been confused. Within KwaZulu-Natal the two species need not be confused, as their distribution (see Figure 2) and altitude ranges do not overlap. However, the $C$. serpyllifolia grows on the Silotwane Hills of Swaziland. closer geographically to the type locality populations of

\footnotetext{
* $C$. ramosissima has not been recorded from KwaZulu-Natal, but is included in the key because it is the only species that has also been recorded from the Free State. Mpumalanga, Limpopo and Lesotho. The key is therefore made more widely applicable by its inclusion.
}

C. browniana than those in the KwaZulu-Natal Drakensberg. Consequently, the exact nature of the relationship between the Mpumalanga populations and the specimens also attributed to $C$. browniana in the KwaZulu-Natal Drakensberg needs to be clarified by molecular techniques.

The identity of $C$. browniana has been further confused by two distinct species being included under the same name within the KwaZulu-Natal Drakensberg. Originally Weimarck recognized the two entities as distinct, describing the specimen Hutchinson 102 separately in the footnotes to $C$. browniana. However. when he later described $C$. spathulata he also included a picture of the latter entity (Esterhuysen 10/83) under the name $C$. browniana. Consequently the two species have been included under the same name (e.g. Hilliard \& Burtt 1987). They are in fact easily distinguishable both in the herbarium and the field and the latter species is here described as $C$. dracomontana. 
Finally, the nature of the juvenile foliage of $C$. browniana has also caused confusion. Whereas the mature foliage has small, entire, narrowly elliptic leaves, the juvenile leaves are toothed. This caused Hilliard \& Burtt (1987) to question whether it could be distinguished from $C$. spathulata. However, mature plants are easily distinguishable, especially if fertile, and the distribution of true C. spathulata does not actually include Hilliard \& Burtt's study area of the southern Drakensberg. In contrast $C$. dracomontana has entire juvenile leaves, which provide another diagnostic character for that species. On the other hand, seedling leaves of $C$. serpyllifolia are also toothed and it is questionable whether juvenile plants of $C$. browniana could be distinguished from them on morphology if the locality was not known.

1. C. browniana Burtt Davy, A manual of the flowering plants and ferns of the Transvaal with Swaziland, South Africa 2: xxi, 316 (1932); Weim.: 56, fig. 13A-D (1934); Hilliard \& B.L.Burtt: 162 (1987) pro parte. Type: Eastern Transvaal [Mpumalanga], 2530 (Lydenburg): Lydenberg, (-AB), Rogers 22985 (BOL, holo.!; K!).

C. spathulata auctt. non Weim.: Hilliard \& B.L.Burtt: 163 (1987).

Erect, medium shrub, up to $0.5 \mathrm{~m}$ high; densely divaricately branched, forming brachyblasts; young stems 0.8-1.2 $\mathrm{mm}$ wide, reddish tinged, hairy; stem hairs upwardly adpressed, 0.2-0.7 mm long. Leaves trifoliate, chartaceous, $0.2-0.4 \mathrm{~mm}$ thick, midrib not prominent above lamina, \pm held straight or slightly curved upwards and towards stem, green with two paler stripes on either side of midrib beneath, glabrous above and beneath;

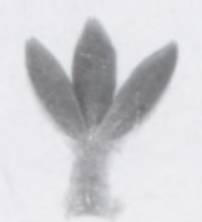

A

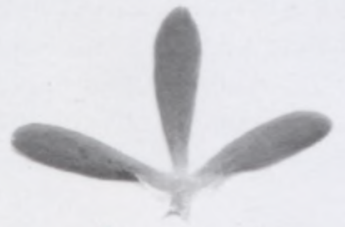

B

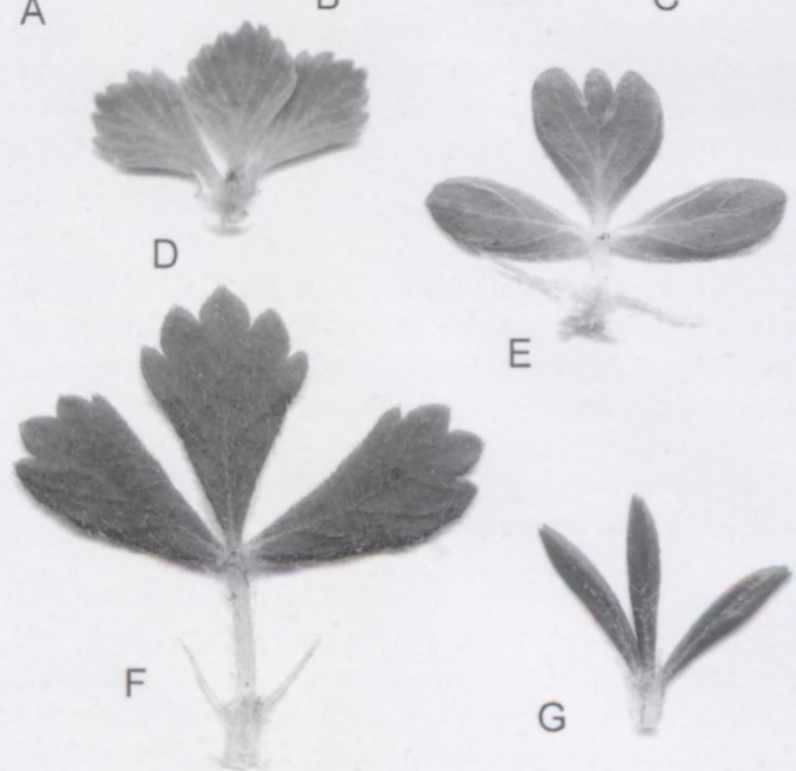

FIGURE 1.-Individual leaves of Cliffortia species, $\times 3$. A, C. bnowniana; B, C. dracomontana; C, C. serpyllifolia; D, C. spathulata: E, C. filicauloides; $\mathrm{F}$, juvenile leaf of $C$. nitidula subsp. pilosa; $\mathrm{G}$, mature leaf of $C$. niridula subsp. pilosa.

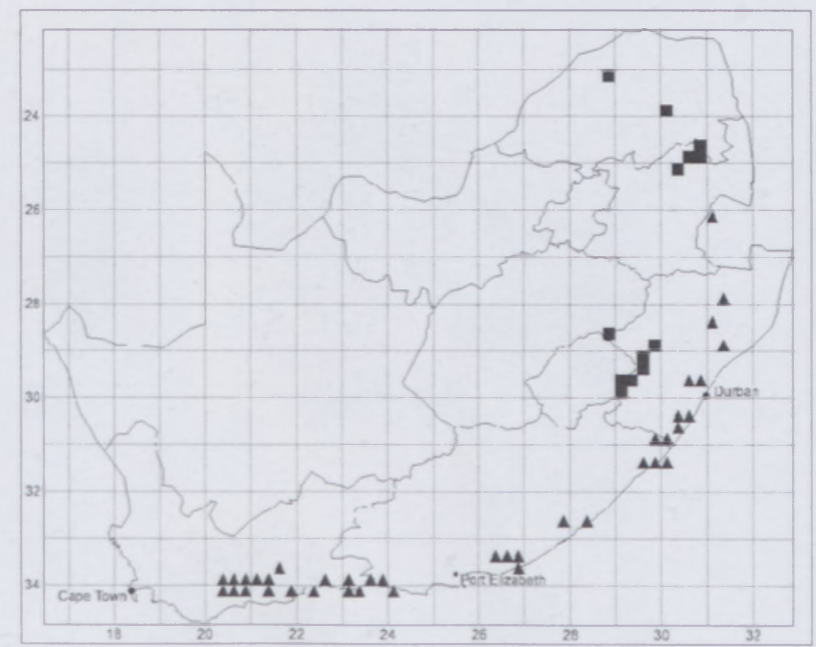

FIGURE 2.-Known distribution of Cliffortia browniana, ; and Cliffortia serpyllifolia, $\mathbf{A}$, in southern Africa.

sheath $0.9-1.4 \mathrm{~mm}$ long, abaxially glabrous, adaxially hairy; stipules $0.4-1.2 \mathrm{~mm}$ long, free, margin ciliate; petiole absent; leaflets elliptic, $1.9-4.3 \times 0.6-1.3 \mathrm{~mm}$, apex acute, margins flat, entire. Flowers solitary in axil of undifferentiated leaves; bracteoles glabrous except for ciliate margins; sepals 4, glabrous. Male flowers unknown. Female flowers: bracteoles 1.3-2.1 mm long, longer than immature receptacle; sepals ovate, $0.9-1.4 \times$ $0.4-0.7 \mathrm{~mm}$, recurved; carpels 1 or 2 ; stigma $0.9-1.3 \mathrm{~mm}$ long, red, feathery, \pm hidden by leaves; immature receptacle $1.0-1.3 \times 0.6-0.8 \mathrm{~mm}$, glabrous, smooth. Achene 2.1-2.4 $\times 1.0-1.3 \mathrm{~mm}$, medium brown, glabrous, faintly or indistinctly ribbed. Flowering time: November to May. Figure 1A.

Habitat: quartzitic sandstone derived soils in full sun, often in damp areas or amongst rocks; altitude 1050 $2500 \mathrm{~m}$.

Distribution: KwaZulu-Natal Drakensberg escarpment from Sehlabathebe in Lesotho to Witsieshoek, with a disjunction to the Mpumalanga Drakensberg escarpment between Graskop and Wolkberg, and an outlying population on Blouberg. Figure 2.

Etymology: not explicitly stated but presumably named after N.E. Brown.

2. C. dracomontana C.M.Whitehouse, sp. nov., C. browniana Burtt Davy affinis, sed foliis obovatis glaucis longioribus, juvenibus foliis integris, bracteolis glabris, fructibus majoribus differt.

TYPE.-KwaZulu-Natal, 2929 (Underberg): 8-11 km NNW of Castle View Farm, headwaters of Mlahlangubo River, (-CB), Hilliard \& Burtt 13561 (NU, holo.!; K!, PRE).

C. browniana auctt. non Burt Davy: Weim.: 56 (1934) pro parte; Weim.: t. 5 (1948); Killick: 127 (1963); D.Edwards: 264 (1967) pro parte; J.H.Ross: 183 (1972); Hilliard \& B.L.Burtt: 162 (1987) pro parte.

Erect, low to medium shrub, up to $0.5 \mathrm{~m}$ high; densely divaricately branched, forming brachyblasts; young 


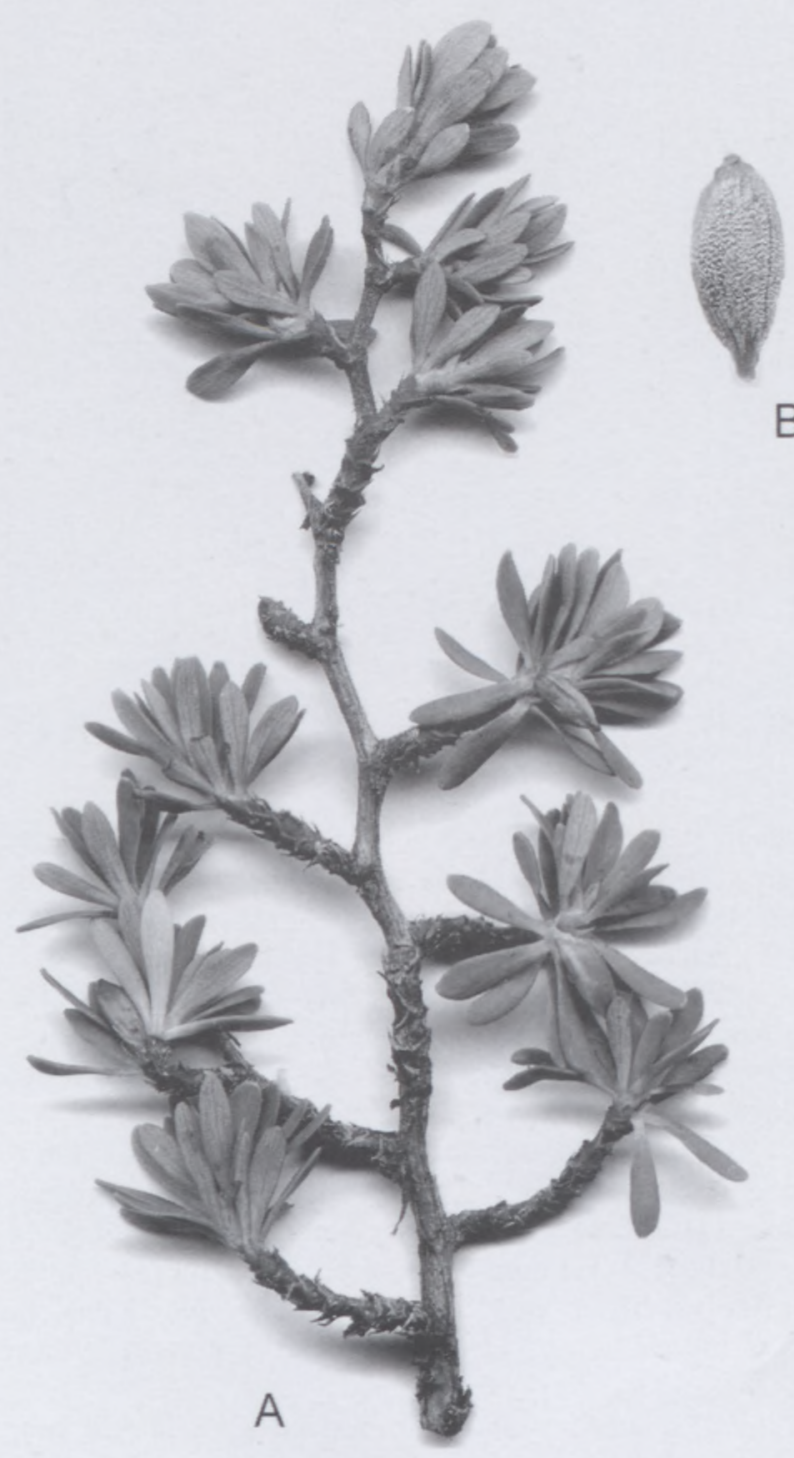

FIGURE 3.-Cliffortia dracomontana. A, fruiting branch, $\times 2.5$; B, achene $\times 5$.

stems $0.7-1.0 \mathrm{~mm}$ wide, often reddish tinged, hairy; stem hairs upwardly adpressed, $0.2-0.5 \mathrm{~mm}$ long. Leaves trifoliate, chartaceous, $0.1-0.3 \mathrm{~mm}$ thick, midrib not prominent above lamina, held \pm straight, glaucous, glabrous above and beneath; sheath $0.9-1.5 \mathrm{~mm}$ long, abaxially glabrous, adaxially markedly hairy; stipules $0.8-1.5 \mathrm{~mm}$ long, free, margin smooth; petiole absent; leaflets elliptic to obovate, $2.8-6.0 \times 0.7-2.1 \mathrm{~mm}$, apex obtuse to rounded, margins flat, entire. Flowers solitary in axil of undifferentiated leaves; bracteoles glabrous, margins smooth; sepals 4, glabrous. Male flowers: pedicel $0.5-0.7 \mathrm{~mm}$ long; sepals broadly ovate, $2.5-3.1 \times 0.9-1.2 \mathrm{~mm}$, acute to acuminate at apex; stamens $4-6$; filaments $1.8-2.3 \mathrm{~mm}$ long. Female flowers: bracteoles 1.7-2.5 mm long, longer than immature receptacle; sepals ovate, $1.2-1.5 \times 0.5-0.6$ mm, recurved; carpel 1; immature receptacle glabrous, smooth. Achene 2.9-4.5 × 1.3-1.8 mm, brown, glabrous, faintly ribbed and slightly tuberculate to rugose. Flowering time: October to November. Figures $1 \mathrm{~B} ; 3$.

Habitat: basalt-derived, well-drained soils and scree in full sun; altitude $2150-3100 \mathrm{~m}$.

Distribution: Drakensberg escarpment, from Mont-auxSources to Ben Macdhui. Figure 4.

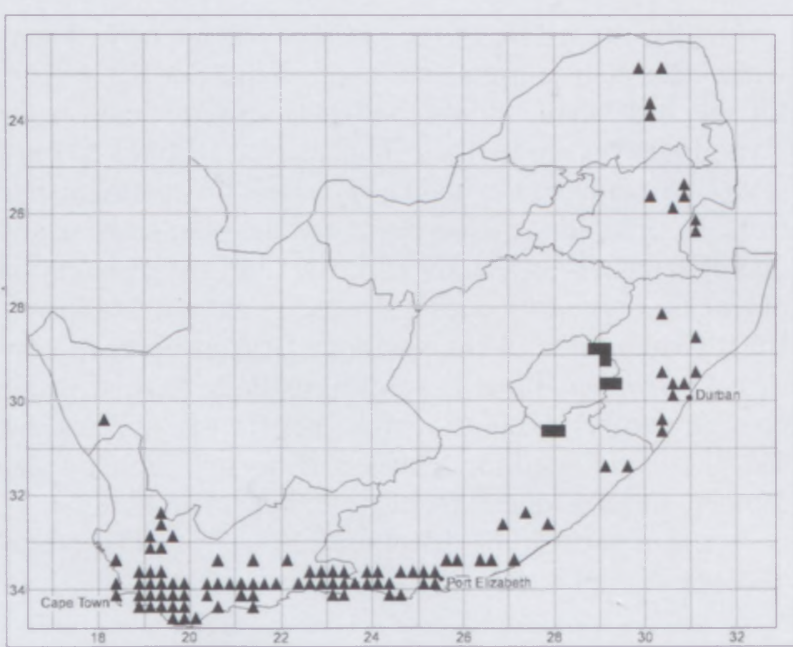

FIGURE 4.-Known distribution of Cliffortia dracomontana, $\mathbf{0}$; and Cliffortia strobilifera, $\mathbf{\Delta}$, in southern Africa.

Etymology: named after the Drakensberg Mountain Range in which it is endemic.

Hilliard \& Burtt (1987) cite two specimens for C. browniana, their number 13561 (incorrectly cited as 13651 ) is C. dracomontana, whereas Guillarmod et al. 218 is a true $C$. browniana. The two species are easily distinguished-C. dracomontana has glaucous leaves, \pm 3-6 mm long, often obovate with rounded apices and smooth stipules, whereas $C$. browniana has green leaves, often with two pale stripes on either side of the midrib beneath, usually less than $4 \mathrm{~mm}$ long, always elliptic, with an acute apex and ciliate stipules. Furthermore, the achenes of $C$. dracomontana are large, 3.0-4.5 mm long, and have glabrous bracteoles, as opposed to $C$. browniana, which has achenes 2.0-2.5 mm long and bracteoles with ciliate margins. The juvenile leaves of $C$. dracomontana show no evidence of any toothing in contrast to C. browniana, which are toothed although still narrowly elliptic.

Preliminary molecular evidence suggests that $C$. dracomontana is more closely related to $C$. spathulata than C. browniana. $C$. spathulata shares with $C$. dracomontana the glaucous leaves, smooth stipules and larger achenes.

3. C. spathulata Weim. in Botaniska Notiser 90: 180, t. 5 (1948); J.H.Ross: 183 (1972). Type: Natal [KwaZulu-Natal] 2929 (Underberg): Amawahqua [Mahwaqa] Mtn, (-DC), Medley Wood 4578 (K, holo.!).

C. browniana auct. non Burtt Davy: Weim.: 56, fig. 13E-H (1934) pro parte.

Erect, medium shrub, up to $1 \mathrm{~m}$ high, resprouting after fire from a single crown; densely divaricately branched, forming brachyblasts; young stems $0.7-1.2 \mathrm{~mm}$ wide, reddish tinged, hairy; stem hairs upwardly adpressed, $0.1-0.6 \mathrm{~mm}$ long. Leaves trifoliate, chartaceous, $0.2-0.3$ $\mathrm{mm}$ thick, midrib not prominent above lamina, curved upwards and towards stem, glaucous, glabrous above and beneath; sheath 0.9-1.5 mm long, abaxially glabrous, adaxially markedly hairy; stipule $0.6-1.1 \mathrm{~mm}$ 


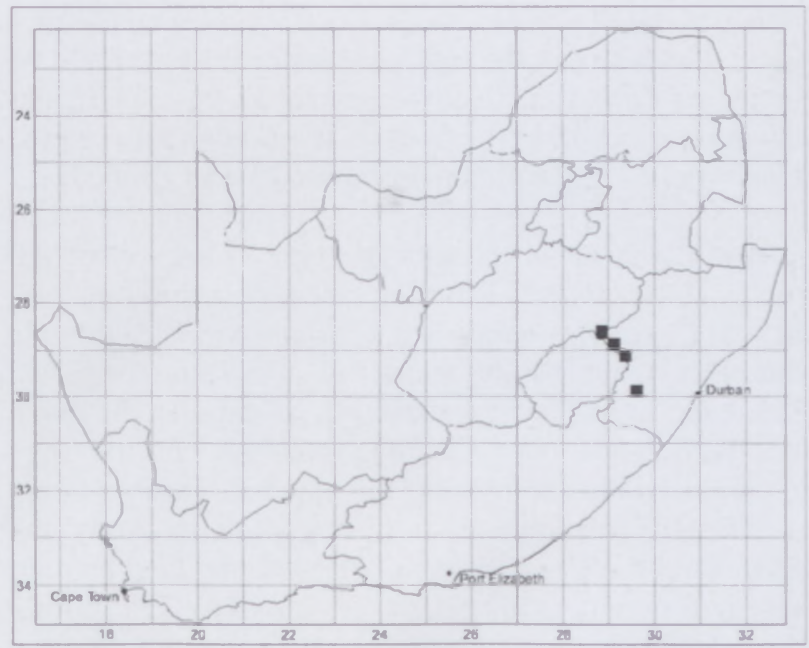

FIGURE 5.-Known distribution of Cliffortia spathulata in southern Africa.

long, free, margin smooth; petiole absent; leaflets broadly obovate, $2.4-6.1 \times 1.2-3.4 \mathrm{~mm}$, base contracted abruptly to form a pseudopetiolule, apex acute to rounded, margins flat, markedly toothed or lobed with 3-7 straight teeth, $0.05-0.25 \mathrm{~mm}$ long. Flowers solitary in axil of undifferentiated leaves; bracteoles glabrous, margins serrate to shortly ciliate; sepals 4 , glabrous. Male flowers: bracteoles 1.6-2.6 mm long; pedicel $0.6-0.9$ $\mathrm{mm}$ long; sepals broadly ovate, $2.6-4.2 \times 1.3-2.3 \mathrm{~mm}$, acute to acuminate at apex; stamens 5 or 6 ; filaments $2.8-4.1 \mathrm{~mm}$ long, red; anthers brownish red. Female flowers: bracteoles $2.2-2.8 \mathrm{~mm}$ long, longer than immature receptacle; sepals ovate, $1.9-2.4 \times 0.7-1.0 \mathrm{~mm}$, recurved; carpel 1; stigma $2.4-3.5 \mathrm{~mm}$ long, white to red, feathery; immature receptacle $1.7-2.2 \times 0.6-0.9 \mathrm{~mm}$, glabrous, smooth. Achene $3.2-3.5 \times 1.0-1.1 \mathrm{~mm}$, medium brown, glabrous, faintly ribbed and slightly tuberculate to rugose. Flowering time: November to December.

Habitat: Clarens Formation sandstone or basalt-derived soils in full sun on well-drained soils; altitude 1800 $2750 \mathrm{~m}$.

Distribution: northern Drakensberg between Witsieshoek and Monk's Cowl (but see note below). Figure 5.

Etymology: spathulata means spoon- or spatula-shaped, referring to the leaflets that have a broad apex, then taper down into a narrow stalk.

The type locality of $C$. spathulata is recorded as Mahwaqa Mtn above Bulwer by Medley Wood. However, this mountain is relatively far from the currently known distribution of the species on the Drakensberg escarpment to the north. Furthermore, $C$. spathulata has not been recollected from that mountain and was not reported in a recent survey (Meter $\mathrm{et} \mathrm{al.} \mathrm{2002).} \mathrm{It} \mathrm{is} \mathrm{there-}$ fore probable that the type locality has been erroneously recorded.

\section{C. linearifolia Eckl. \& Zeyh.}

Hilliard \& Burtt (1987) note that this species has two forms in the southern Drakensberg, one forming tall vir-

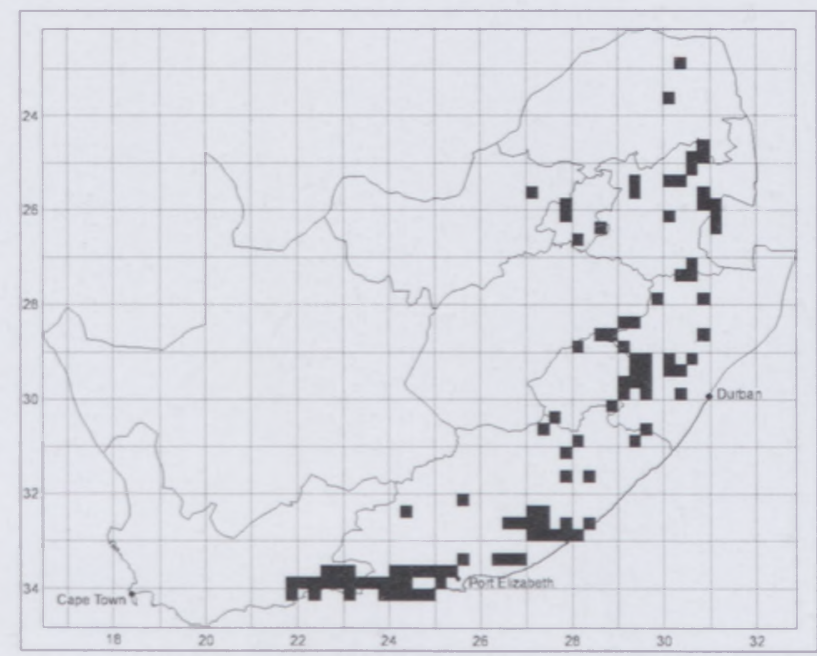

FIGURE 6.-Known distribution of Cliffortia linearifolia in southem Africa.

gate shrubs with unifoliate foliage and the other shorter and densely branched with trifoliate leaves. The unifoliate form is found in wetter areas, such as along watercourses, whereas the trifoliate form is found on rocky outcrops and drier slopes. However, both forms have similar distribution patterns (Figure 6) and it is not possible to determine from morphology alone whether they constitute distinct varieties or just ecotypes. Molecular work and/or transplantation experiments are needed to examine these two entities to establish the degree of phenotypic plasticity within the species.

5. C. nitidula (Engl.) R.E.Fr. \& T.C.E.Fr. subsp. pilosa Weim. and C. filicauloides Weim.

One of the most marked occurrences of dimorphism between juvenile and mature leaves is found in $C$. nitidula (Engl.) R.E.Fr. \& T.C.E.Fr. subsp. pilosa Weim. (Figure 7). Whereas the mature foliage has needle-shaped leaflets typical of many species of Cliffortia, the leaves of seedlings and resprouting growth after fire are trifoliate with a petiole and broadly toothed leaflets. It has therefore been frequently confused with the northern

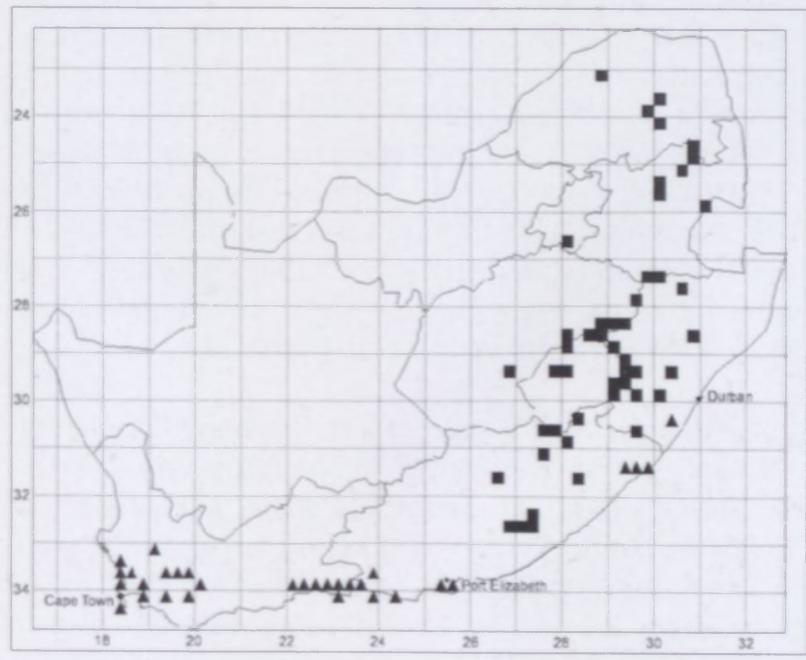

FIGURE 7.-Known distribution of Cliffortia nitidula subsp. pilosa. $\mathbf{m}$; and Cliffortia odorata, $\mathbf{\Lambda}$, in southern Africa. 


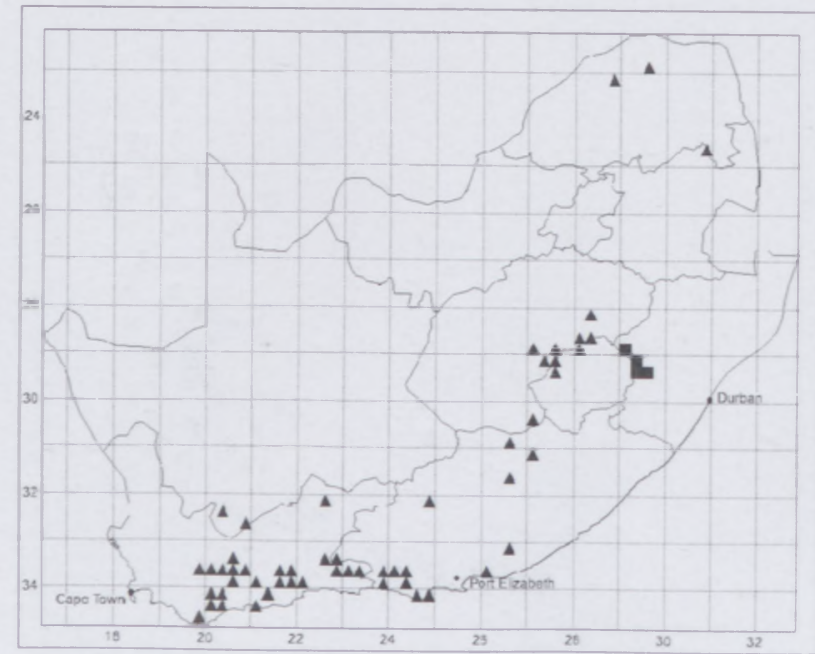

FIGURE 8.-Known distribution of Cliffortia filicauloides, $\mathbf{n}$; and Cliffortia ramosissima. $\boldsymbol{\Delta}$, in southern Africa.

Drakensberg endemic $C$. filicauloides (Figure 8), a species whose closest relatives are in fact found in the CFR (Whitehouse 2003). In the field, confusion is unlikely as the habit of $C$. nitidula subsp. pilosa is always erect, whereas $C$. filicauloides forms arching stems that sprawl across boulders and down slopes, and the juvenile nature of the shoots is usually evident. Furthermore, shoots with juvenile leaves appear to be always sterile, thus flowering material will belong to $C$. filicauloides. Sterile herbarium material can best be distinguished by examining the lateral leaflets, which are toothed and similar in size and shape to the middle leaflet in $C$. nitidula subsp. pilosa, but generally untoothed and narrower than the middle leaflet in $C$. filicauloides.

\section{Subdivision of C. paucistaminea Weim. and typification of C. galpinii N.E.Br.}

C. paucistaminea Weim. is a widespread species from the Outeniqua Mountains to the KwaZulu-Natal Drakensberg. It is easily recognizable over most of its range by its four-sepalled flowers and needle-shaped leaves that occur on closely overlapping brachyblasts. However, two distinct forms can be recognized. Between George and Port Elizabeth, the leaves are strongly curved upwards and towards the stem, accentuating the overlapping nature of the brachyblasts. In addition, the leaflets are quite fine, $0.3-0.5 \mathrm{~mm}$ wide, and the young stems as a whole have a feathery appearance, resembling the Western Cape species $C$. exilifolia Weim. (which has only three sepals). To the north and east of Port Elizabeth the leaves are straighter or sometimes recurved away from the stem, when the brachyblasts then appear starlike, and the leaflets are generally broader.

Unlike $C$. linearifolia Eckl. \& Zeyh. above, the two forms also have a geographical separation and therefore attributing them a taxonomic rank is appropriate. However, the variation could be the result of clinal differentiation associated with climatic factors: the southern populations are subject to year-round rainfall, whereas those further north have an increasingly dominant summer rainfall pattern. Morphometric studies along with population-level molecular work are needed across the range of the species to determine if there is continuous gene flow between the two varieties or if they would be better regarded as distinct species. In this case, particular attention needs to be focused on the border between the two varieties in the mountains around Port Elizabeth.

Weimarck identified that the type collection of the name C. galpinii N.E.Br. included two different elements: $C$. paucistaminea and $C$. ramosissima Schltr. He therefore regarded the name as a nomen confusum. However, this is an unsatisfactory solution as the name has precedence over $C$. paucistaminea but not over $C$. ramosissima. To prevent the name $C$. galpinii being accidentally resurrected, it is important to typify the name with the $C$. ramosissima element and thereby relegate it to synonymy. The Kew collections of Galpin 1607 are ambiguous with regard to their locality, stating 'Hangklip and Andriesberg Mountains' for both specimens. However, the Bolus and Grahamstown specimens state only Andriesberg for the $C$. ramosissima element, whereas the BOL and PRE specimens both state Hangklip Mtn for the $C$. paucistaminea element. It would therefore seem logical to deduce that Andriesberg should now be attributed as the type locality.

6. C. paucistaminea Weim. in Botaniska Notiser 1933: 151, fig. 4c, d (1933); Weim.: 64, fig. 16A-E (1934); J.H.Ross: 183 (1972); Hilliard \& B.L.Burtt: 162, t. 6C (1987); Pooley: 150 (1998); Fellingham: 615 (2000). Type: Basutoland [Lesotho], Cooper 690 (K. holo.!; B, BOL!, W, Z).

C. galpinii auct. non N.E.Br. sensu stricto: N.E.Br.: 122 (1901) pro parte.

C. juniperina auct. non L.f.: Jacot-Guillarmod: 186 (1971).

Erect, medium to tall shrub, up to $2 \mathrm{~m}$ high, resprouting after fire and sometimes spreading clonally; densely divaricately branched, forming brachyblasts, which are closely overlapping; young stems $0.8-1.7 \mathrm{~mm}$ wide, hairy; stem hairs upwardly adpressed, $0.2-0.6 \mathrm{~mm}$ long. Leaves trifoliate, chartaceous, $0.1-0.4 \mathrm{~mm}$ thick, midrib keeled and prominent, green with two paler stripes on either side of midrib beneath, glabrous above and beneath; sheath 0.6-1.5 mm long, abaxially glabrous, adaxially glabrous to markedly hairy; stipules $1.5-2.3 \mathrm{~mm}$ long, free, margin smooth; petiole absent; leaflets linear to needle-shaped, 5.1-10.2 $\times 0.3-0.8 \mathrm{~mm}$, apex sharply acuminate, $0.4-0.8 \mathrm{~mm}$ long, margins flat, minutely serrulate to scabrid. Flowers solitary in axil of undifferentiated leaves; bracteoles hairy, margins serrate to shortly ciliate; sepals 4, or very rarely 3 , glabrous. Male flowers: bracteoles $0.9-1.8 \mathrm{~mm}$ long; pedicel $0.3-0.8 \mathrm{~mm}$ long; sepals broadly ovate, $2.2-3.6 \times 0.9-1.5 \mathrm{~mm}$, acute to acuminate at apex; stamens $4(-6)$; filaments $1.4-3.7 \mathrm{~mm}$ long, reddish; anthers yellow to brownish red. Female flowers: bracteoles 1.6-2.6 mm long, longer than immature receptacle; sepals narrowly ovate, $1.1-1.7 \times 0.3-0.5$ $\mathrm{mm}$, erect to recurved; carpel 1; stigma $2.5-3.7 \mathrm{~mm}$ long, greenish white, feathery, hidden at base of leaves; immature receptacle $1.0-1.8 \times 0.6-0.9 \mathrm{~mm}$, glabrous, clearly ribbed. Achene 2.1-3.3 $\times 0.9-1.2 \mathrm{~mm}$, pale yellowish brown, glabrous; ribs $8-16$, rounded to acute, $0.1-0.2$ mm wide. 


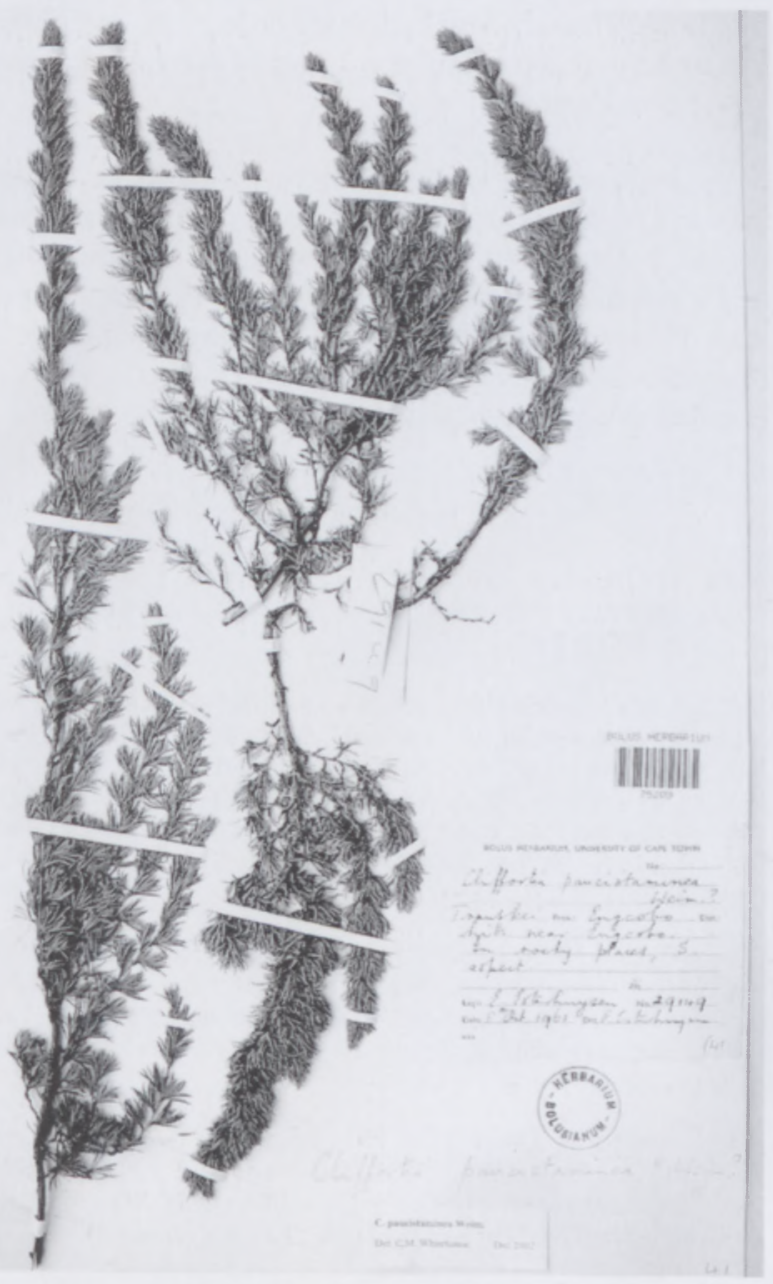

FIGURE 9.-Example specimen of Cliffortia paucistaminea var. paucistaminea, Transkei, Engcobo District, hills near Engcobo, Esterhuysen 29149 (BOL).

Etymology: paucistaminea means few stamens, referring to the male flowers that only have 4 stamens, although a number of other species also have that few.

\section{6a. var. paucistaminea}

Leaflets $0.4-0.8 \mathrm{~mm}$ wide, held straight or curved downwards and away from the stem. Flowering time: predominantly September to February. Figure 9.

Habitat: found in humus-rich soil over sandstone rocks in full sun; altitude 0-2 $350 \mathrm{~m}$.

Distribution: widespread from the Suurberg Mountains along the Drakensberg escarpment as far as Giant's Castle, with outlying populations along the Wild Coast and KwaZulu-Natal lowlands as far north as Nkandla. Figure 10.

6b. var. australis C.M. Whitehouse, var. nov., a var. paucistaminea ramulis plumosis differt.

TYPE.-Eastern Cape, 3424 (Humansdorp): Witte Els Bosch [Witelsbos], flats, (-AA), Fourcade 2114 (BOL, holo.!; K!, LD, NBG!, PRE).

Leaflets $0.3-0.5 \mathrm{~mm}$ wide, curved upwards and towards stem, giving the branches a feathery appearance.

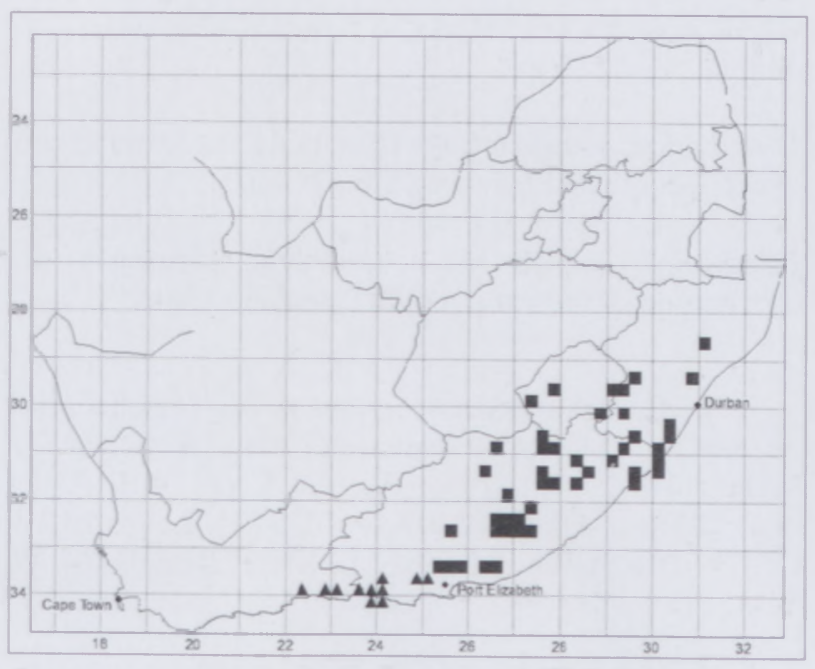

FIGURE 10.-Known distribution of Cliffortia paucistaminea var. paucistaminea, $\mathbf{E}$; and Cliffortia paucistaminea var. australis, $\boldsymbol{A}$, in southern Africa.

Flowering time: predominantly November to April. Figure 11 .

Habitat: humus-rich Table Mountain Sandstone derived soils, in full sun and on well-drained soils, but areas

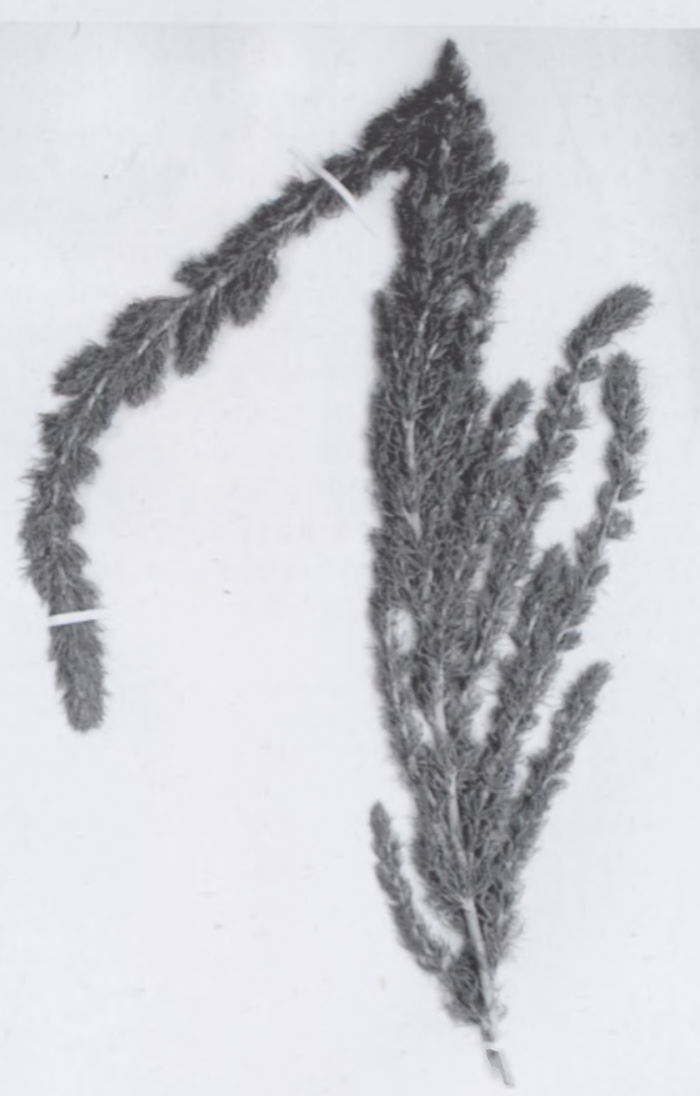

IHIHIIII

FIGURE 11.-Holotype of Cliffortia paucistaminea var. australis, Witte Els Bosch, flats, Fourcade 2114 (BOL). 
where it grows are subject to frequent rain and cloud; altitude $50-1550 \mathrm{~m}$.

Distribution: southern Cape mountains and lowlands between George and Uitenhage. Figure 10.

Etymology: australis means southern, referring to the distribution of the variety in the southern Cape.

7. C. ramosissima Schltr. in Botanische Jahrbücher 24: 444 (1897); Weim.: 73, fig. 18L-R (1934); Weim.: 419 (1946). Type: Western Cape, 3419 (Caledon): Elim, (-DB), Schlechter 7633 (B, holo.; BOL!, COI, G-DEL, GRA, K!, HBG, L, NH, P, PRE, SAM, W, WAG, Z).

C. galpinii N.E.Br.: 122 (1901) pro parte. Lectotype, here designated: Eastern Cape, Queenstown District, Andriesberg, Galpin 1607: C. ramosissima element (K, lecto.!; BOL!, GRA!).

\section{C. repens Schltr. and C. erectisepala Weim.}

Weimarck described $C$. erectisepala from a single collection from Paarl Mountain. He subsequently commented on collections from Franschhoek (Weimarck 1940) and Swellendam (Weimarck 1946). C. repens Schltr. he applied to unifoliate, needle-leaved collections from Uitenhage to Pietersburg. However, morphologically the collections from Uitenhage to Grahamstown are closer to $C$. erectisepala, having shorter, narrower leaves, upright erect habit, and non-spreading sepals. More recent collections have extended the range of $C$. erectisepala from Gifberg in the north to Rooiberg in the Little Karoo. The species in general is very inconspicuous and the current study has revealed that it is in fact much more common and widespread with many new localities being recorded. Consequently, the disjunction between Western Cape populations and the narrow-leaved Eastern Cape populations of $C$. repens is not as marked as originally thought. Therefore, these populations are now included in $C$. erectisepala, whereas the range of true $C$. repens is reduced and extends only as far south as Baziya Mtn near Umtata. This change is significant biogeographically, as $C$. repens is no longer part of the Cape Flora and is better regarded

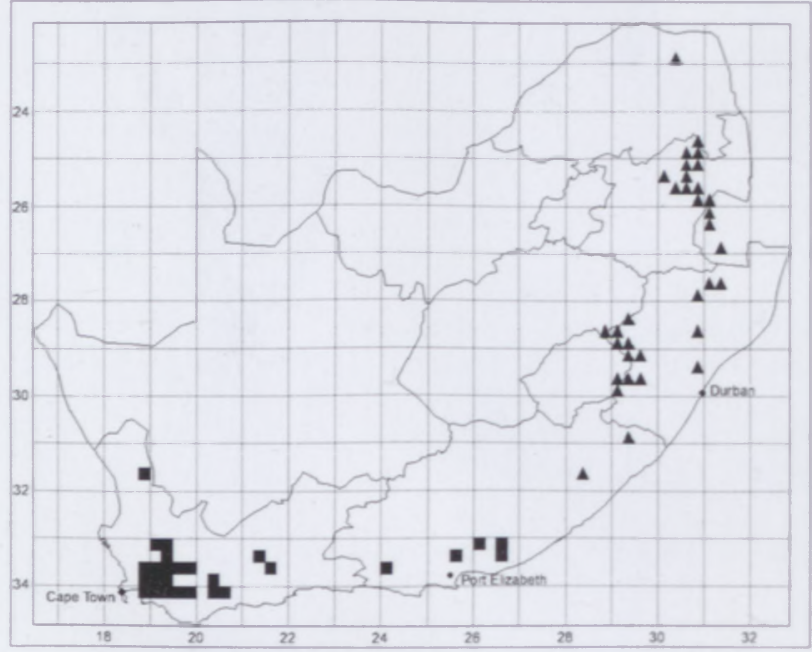

FIGURE 12.-Known distribution of Cliffortia erectisepala, and Cliffortia repens, $\mathbf{\Delta}$, in southern Africa. as a broad Drakensberg endemic, whereas $C$. erectisepala can be counted as a Cape Ubiquist (sensu Weimarck 1941) (see Figure 12).

A single collection is incongruous with this re-organization. The sheets are labelled as collected by Thorncroft (in Herb. Rogers 19187) from Barberton and are typical of $C$. erectisepala, although only male flowers are present. However, no other collections have been made in this well-collected area that resemble $C$. erectisepala and it is therefore presumed that the locality is erroneous.

\section{SPECIMENS EXAMINED}

Abbott 177 (6a) PRE. Acocks 10217 (1) PRE; 11462 (1) NBG, PRE 12037 (6a) PRE; 13838, 18690, 20159, 21884 (6a) K. PRE. Acocks \& Hafstrom 571 (4) PRE.

Balkwill, Manning \& Meyer 790 (5) K, NU; 792 (5) NU; 793 (3) NU. Balkwill, Manning et al. 1030 (6a) NU. Baur 494 (8) K. Bayer 815 (8) NU. Bayliss 493, 1347 (6a) PRE. Bean, Viviers \& Cloete 2274 (6a) BOL. Bews 1413 (8) NU. Bolus 250 (6a) BOL. Bond 1210 (6b) BOL. PRE. Britten 4663 (6a) GRA, PRE; 6408 (6a) GRA. Bruce 495 (8) K, PRE. Buitendag 827 (8) K. NBG, PRE. H. \& J. Burrows 4720 (8) GRA. Burtt Davy 1560 (8) BOL, PRE.

Comins 581 (4) NU. Compton 7313 (8) NBG; 10458 (6b) NBG; 19176 (6a) NBG; 19746, 19789, 22377 (8) NBG; 23500 (6b) NBG; 24742 (8) NBG; 26285, 27606 (8) K, NBG, PRE; 28510, 30531 (8) NBG, PRE. Cooper 690 (6a) BOL, K. Crewe 24 (5) NU. Curator Pretoria Bot. Garden 21565 (8) PRE.

Davidson \& Mogg 33405 (8) K, PRE. Deall 2303 (8) PRE. Devenish 1976 (5) NU. Dickin 4 (6b) BOL. Dieterlen 1103, 1203 (6a) NBG PRE. Dohne Research Institute 4 (6a) GRA. Dold 815 (6a) GRA Downing 104 (4) NU. Drège 5381 (4) K. Dyer \& Collett 4700 (8) PRE.

Edwards 244 (4) NU; 596 (2) NU, PRE; 928 (4) NU; 976 (4) NU, PRE; 2013 (3) NU; 2233 (8) K, NU, PRE; 2235, 2248 (5) NU; 2456 (1) K NU, PRE; 4054 (8) K, PRE. Esterhuysen 4569 (6b) BOL; 6810 (6b) BOL, PRE; 7930 (8) BOL; 8843 (3) BOL; 8846 (4) BOL; 10180 (3) BOL, K; 10181 (5) BOL, K; 10183 (2) BOL; 10184 (8) BOL, K, NBG, NU; 10816 (6b) BOL; 10854 (6b) BOL, K; 12867 (8) BOL, PRE 12871 (3) BOL; 12886 (2) BOL; 13222,13259 (6a) BOL; 13578 (6b BOL; 14527 (8) BOL, NBG, PRE; 14528 (8) BOL; 15482 (2) BOL. NBG, PRE; 15484 juvenile (5) BOL; 15485 (3) BOL; 15489 (8) BOL, NBG; 15635 (3) BOL; 16272 (6b) BOL; 16770 (6b) BOL, NBG, PRE 17342 juvenile (5) BOL, PRE; 18661 (2) BOL, NBG; 18662 (3) BOL, PRE; 18684 (5) BOL; 21447 (1) BOL, K. PRE; 21687 (2) BOL; 27113 (6b) BOL, PRE; 27374 (6b) BOL; $2754 l$ (6b) BOL, PRE; 27846 (8) BOL; 29149 (6a) BOL, K. Evans 663 (8) K, PRE.

Fellingham 1631 (6a) NBG, PRE; 1632, 1671, 1672 (6a) NBG Feltham 155 (5) NU. Forrester \& Gooyer 204 (1) PRE. Fourcade 2114 (6b) BOL, K, NBG, PRE. Galpin s.n. (8) BOL; 1607 (6a) BOL, K, PRE; 2255, 8307 (6a) PRE; 9439 (4) K, PRE; I3072 (8) K, PRE Germishuizen 5778 (8) PRE. Gerrard 1568 (8) K. Gerstner s.n. (5) PRE; 3520 (4) PRE; 3934 (5) PRE. Gibbs Russell 3493A (6a) BOL, GRA, PRE, UFH. Giffen 342 (6a) GRA, PRE, UFH. Gilbert 7593 (2) PRE. Gillies 60 (4) NU. Glen 380 (6a) NBG; 2444 (4) PRE. Gordon Gray 887 (4) NU. Goulimis s.n. (6a) BOL. Grice s.n. (4) NU, (6a) NU. Grobbelaar 2618 (1) PRE.

Hepburn 125 (6a) GRA. Hilger 7 (6a) PRE. Hilliard I778A (4) NU; 2648, 3031 (6a) NU; 4708, 8165 (4) NU; 8228 juvenile (5) NU. Hilliard \& Burtt 6532 (6a) K. NU, PRE; 9314 (4) NU; 12481, 12581, 13284 (6a) NU; 13285 (6a) K, NU; 13331 (8) NU; 13341 (5) NU; 13342 (1) NU; 13416 (4) NU, PRE; 13428 (5) NU; 13442 (4) K. NU; 13465 (8) NU; 13508,13513 (4) NU; 13561 (2) K, NU, PRE; 13563 (5) NU; 13592 (4) K, NU; 13653 (4) K, PRE; 13689 (5) NU; 13865 (6a) K, NU; 13866 (6a) K. NU, PRE; 13894 (6a) NU; 14011 (4) NU; 14035 (6a) NU; 14071 (8) K, PRE; 14292 (8) K, NU, PRE; 14323 (1) NU, PRE; 14383 (8) K, NU, PRE; 14459 (8) K, NU; 14502,14503 (6a) NU; 14506 (6a) K, NU; 14510 (6a) K; 14655 (6a) K, NU, PRE; 14753 (6a) K. NU; 14887 (4) NU; 14888 (5) NU, PRE; 14925 (6a) NU, PRE 14965 (4) NU: 15021 (2) K. NU; 15105 (4) K, NU, PRE; 15172 (4) NU, PRE; 15266 (1) K, NU, PRE; 15378 juvenile (5) K, NU; 15397 (4) 
K. NU. PRE: 15403,15430 (8) K. NU, PRE: 15447 (5) K. NU, PRE; 15456 (3) K. NU; 15505 (5) NU: $/ 5510$ (5) NBG. NU; 15542 (5) NBG: $1559 /$ (6a) NU; 15592 (4) NU: 15634 (8) K. NU. PRE; I5643(6a) K. NU, PRE: 15644 (6a) NU. PRE: 15667,15672 (4) NU: 15673 (4) K. NU: 15789 (5) K. NU. PRE: 15790 (4) K. NU. PRE: 15815 (4) NU; 15816 (5) NU. PRE: 16273 (8) K. NU. PRE: $16274(5) \mathrm{NU}: 16286(4)$ K. NU. PRE: 16.304 (3) K. NU: 16332 (6a) K. NU. PRE: 16333 (6a) K. NU; /6422 (2) K. NU. PRE; /6489 juvenile (5) NU; /6605 (2) K. NU: 16762 (8) K. PRE; 16870,16871 (4) K. NU. PRE: 16986 (8) NU: 16987 (4) NU: 17012 (4) K. NU. PRE; 17025 (8) K. NU. PRE; 17030 (4) K. NU. PRE; 17077 (6a) NU. PRE; 17095 (6a) K. NU. PRE: /71/0 (4) NU; 17169 (8) K. NU. PRE: 17225 (1) K. NU. PRE: 17667 juvenile (5) K. NU, PRE: 17668 (8) K. NU. PRE: 17677,17681 (1) K. NU. PRE: 17697 (3) K. NU. PRE: 17724 (8) K. NU, PRE: /7761, 17805 (4) $\mathrm{NU}: 17955$ (6a) NU. PRE: 17956 (4) K. NU: 17994 (1) NU: 18058 , 18180 (5) NU; 18284 (5) K. NU. PRE: 18315 juvenile (5) NU: 18329 (6a) K. PRE; 18330 juvenile (5) K. NU. PRE: 18358 (8) K. NU. PRE: 18536 juvenile (5) K. NU. PRE: $1868 /$ juvenile (5) NU: 18837 (6a) K. NU. PRE. Hilliard, Burnt \& Manning 15955 (6a) NU: 15965 (4) NU. PRE; 16026 (1) K. PRE: 16061.16062 (1) NU: 16069 (6a) NU: 17261 juvenile (5) NU; 17296 (4) NU. Huntley 409 (5) NU. Hurchinson 4534 (8) K: 4543 (5) K: 4550 (3) K: 4580 (2) K. Hutchinson \& Gillelt 4314 (8) K. Hutchinson. Forbes \& Verdoorm 72 (3) PRE.

Jacobsen 2272 (8) PRE. Jacor-Guillarmod 3958 (6a) PRE; 7959 (6a GRA. Jacot-Guillarmod. Getliffe \& Mzamane 2/8 (1) GRA. K. PRE. Johnstone 209 (6a) NU. Jordaan 2910 (1) PRE

Keet STE1.3384 (6h) NBG, (8) NBG. Kemp 122.3 (8) PRE. Kensit \& Coporn in NBG. 150/14 (6b) BOL. Kerfoot. Forrester \& Goover $3 /$ (8) PRE. Killick 1109 (8) K. PRE: 1932 (3) PRE. Killick \& Vahrmever $37 / l$ (6a) K. PRE. Kluge $23 / 3$ (8) NBG. PRE. Krinaun 310 (8) PRE: 782 (1) PRE. Kuntze s.n. (5) K.

lambinon \& Reekmans 82/460 (8) PRE. Leighton 2697 (6a) BOL: 2998 (6a) BOL. PRE; $3 / 27$ (6a) BOL: 3267 (8) BOL. Levyns 6905 (6a) BOL: 8240 (4) BOL: 8267,8273 (8) BOL: 8302 (5) BOL: 8303 juve nile (5) BOL: 8308,9408 (8) BOL: 9410 juvenile (5) BOL: 9842,9856 (6a) BOL: 10482 (6b) BOL.

MacDeverte 1574 (6a) PRE. Martin 9067 juvenile (5) GRA. McClean \& Baver 5 (8) BOL. K. NU. PRE; 103 (5) NU. McDonald 88 (6b) PRE: 240) (8) K. NU, PRE. Medley Wood s.n. (8) BOL: 4449 (8) K: 4578 (3) K: 5987 (8) K: 7903 (6a) BOL. K. Meeuse 9981 (1) PRE. Meyer 58 (8) PRE. Morris $44 I$ (5) NU. Mudd s.n. (8) BOL. K.

Nel 221 (8) NBG. PRE. Neser NFl969 (4) PRE. Ngwenva 953 (6a) PRE. Onderstall 170 (1) PRE. Ons s.n. (8) NBG.

Palmer 1412 (6a) GRA. Phillips s.n. (6a) NU; s.n. (5) NU; s.n. (8) NU. Pole Evans 967, 968 (8) K. PRE. Prior 60 (8) K.

Rehmann 6927 (5) K. J. \& B. Rennie 168A, I68B (6a) GRA. M. Rennie 120 (4) NU. Roheris 2496 juvenile (5) PRE: 2676 juvenile (5) PRE. Rogers 21565 (8) K: 21591 (8) BOL. K: 22985 (1) BOL. K. Ross 195 (8) NU: 1755 (8) K. NU. PRE: Ruch 2039 (4) K. Rudatis 2063 (6a) NBG.

Scharf 1317 (6b) PRE. Schelpe 440) (4) NU: 673 (5) NU: 1092 (4) NU: 1381 (2) NU. PRE: 7195 (8) BOL. PRE. Schlechter $33 / 8(4)$ BOL. K: 5492 (6b) K. PRE; 6 $\$ 94$ (8) BOL. PRE. Schmit: 9223 (6a) NU. PRE. Sidey 2015 (2) PRE. Sim 19430 (6a) NU. PRE: $1943 /$ (4) PRE: 19432 (4) NU. PRE. Shead 23 (4) NU. Smis 631 juvenile (5) PRE. Siayner in Herh. Bolus 19865 (6a) BOL. Ston 3/16 (6a) PRE: 3/90 (6a) GRA. PRE: $4(x) 3$ (8) GRA. K. PRE: 5448 (8) K. PRE. Sirey 6933 (6a) NU, PRE: 7692 (4) K, NU: //272 (5) NU. Sutherland s.n. (6a) K.

Taylor 4451 (6b) K. NBG. PRE. H. Thode 1598 (8) K. J. Thode 3286 , 4330 (8) NBG; 4595 (5) NBG; 6.356 (8) NBG. Van Daclen $12 /$ (6b) NBG. PRE. Van der Schijff 1480 (1) K: 4480 (1) PRE: 5588 (1) K. PRE. Van der Schut 4.475 (8) K. Van der Wals 367 (6a) PRE. Victor 767 (6a) GRA: 1238 (6a) PRE. Von Gadow 472 (6a) GRA

Wager 181 (8) K. PRE. Werdermann \& Oberdieck 2/8I (8) K. PRE. C. \& A. Whitehouse 56 (6a) $\mathrm{BOL}, 286$ (2) BOL: 287 (3) BOL: 289 (1) BOL; $290(8)$ BOL; 291. 292 (4) BOL: 296 (1) BOL; 297 (6a) BOL. 298 (6b) BOL: 299 (8) BOL: 323 (6a) BOL: 325 (2) BOL: 326 (1) BOL. Wilkinson s.n. (2) GRA. Williams 342 (6a) PRE. Wilms 595 (8) K. Wirminghaus 982 (5) NU: 1054 (4) NU. Whlie in Medley Word l(1) $29(8) \mathrm{K}$.

\section{ACKNOWLEDGEMENTS}

This study was funded by a Leverhulme Trust, Study Abroad Studentship, with assistance from a J.W. Jagger International Scholarship, and was initiated by Prof. H.P. Linder. I wish to thank the KwaZulu-Natal Parks Board for granting me a collecting permit and the various sectional managers of the uKhahlamba-Drakensberg Park for allowing me to collect specimens. I also thank the curators of BOL, GRA, K, NBG, NU and PRE for permission to examine their collections or in sending loans.

\section{REFERENCES}

BROWN. N.E. 1901. Diagnoses Africanae 13. Kew Bullerin 1901: $119-138$

BURTT DAVY. J. 1932. A manual of the flowering plants and ferms of the Transiaal with Swaziland. South Africa 2. Longmans. Green. London.

EDWARDS. D. 1967. A plant ecological survey of the Tugela River Basin. Memoirs of the Botanical Suney of Soush Africa No. 36

FELLINGHAM. A.C. 1993a. Observations on Cliffortia micrantha. Bothalia 23: 65.66 .

FELLINGHAM. A.C. 1993b. Cliffortia fasciculasa, a superfluous name for $C$. amplexisripula. Bothalia 23:67.68.

FELLINGHAM. A.C. 1994. Clifforia longufolia . a "good' species or should it be a variety under $C$. strobilifera? Bothalia 24: 31-34

FELLINGHAM. A.C. 1995. A new species of Cliffortia from the Swartberg. Borhalia 25: 104-107.

FELL.INGHAM. A.C. 2000. Cliffortia. In P. Goldblatt \& J.C. Manning. Cape plants. A conspectus of the Cape flora of South Africa. Sirelitzia 9: 608-616. National Botanical Institute, Cape Toun and Missouri Botanical Garden.

FELLINGHAM, A.C. 2003. A new serotinous species of Cliffortia L. (Rosaceae) from Northern Cape. South Africa and section Arborecie emended. Bothalia 33: 41-47.

GOLDBLATT. P. \& MANNING. J.C. 2000. Cape plants. A conspectus of the Cape flora of South Africa. Strelizzia 9. National Botanic Institute. Cape Town and Missouri Botanical Garden.

GOLDING, J.S. 2002. Southern African plant Red Data Lists. Southem African Botanical Diversity Network Report No. 14.

HILLIARD. O.M. \& BURTT. B.L. 1987. The botany of the southern Natal Drakensberg. Annals of Kirstenbosch Botanic Gardens 15 JACOT-GUILLARMOD. A. 1971. Flora of Lesotho. Cramer. Lehre.

KILLICK. D.J.B. 1963. An account of the plant ecology of the Cathedral Peak area of the Natal Drakensberg. Memoirs of the Botanical Survey of South Africa No. 34

L.INDER. H.P. 2001. On areas of endemism. with an example from the African Restionaceae. Systematic Biology: 50: 892-912.

METER. E.B.. EDWARDS. T.J., RENNIE, M.A. \& GRANGER. J.E 2002. A checklist of the plants of Mahwaqa Mountain. KwaZulu-Natal. Bothalia 32: 101-115.

OLIVER. E.G.H \& FELLINGHAM. A.C. 1991. A new species of Clifforia from the south-westem Cape. Bothalia 21: 60-62.

OLIVER. E.G.H \& FELLINGHAM. A.C. 1994. A new serotinous species of Cliffortia (Rosaceae) from the southwestern Cape with notes on Cliffortia arborea. Bothalia 24: 153-162.

POCLEY. E. 1998. A field guide to wild flowers: KwaZulu-Natal and the eastern region. Natal Flora Publications Trust. Durban.

ROSS. J.H. 1972. Flora of Natal. Memoirs of the Botranical Suniey of South Africa No. 39

SCHLECHTER. R. 1897. Plantae Schlechterianae novae vel minus cognitae describuntur 1. Botanische Jahrbücher 24: 434-459.

WEIMARCK. H. 1933. New species in the genus Clifforia. Botaniska Noriser 143-164

WEIMARCK. H. 1934. Monograph of the genus Cliffortia. Hảkan Ohlsson. Lund

WEIMARCK. H. 1940. Some notes on the genus Clifforia. Botaniska Notiser 51: 399-402

WEIMARCK. H. 1941. Phytogeographical groups, centres and intervals within the Cape Flora. Lunds Universitet Arsskrift 37 3-143.

WFIMARCK. H. 1946. Further notes on the genus Clifforia. Botanisha Notiser 80: $407-420$.

WEIMARCK. H 1948. The genus Clifforia. a taxonomical survey Boranisha Notiser 9(): 167-203. 
WEIMARCK, H. 1953. Two new Cliffortia species from the Cape Province. Botaniska Notiser 106: 78-80.

WEIMARCK. H. 1959. Four new Cliffortia species. Botaniska Notiser
112: 73-79

WHITEHOUSE, C.M. 2003. Systematics of the genus Cliffortia $L$. (Rosaceae). Ph.D. thesis, University of Cape Town. 